\title{
Challenges and Constraints Faced by Maitris in Delivering Veterinary Services in Chhattisgarh, India
}

\author{
K. Chandraker ${ }^{1}$, B.C. Das ${ }^{1 *}$, P. Swain ${ }^{1}$, D.P. Swain ${ }^{1}$, \\ A. Kumar Pandey ${ }^{2}$ and B.K. Singh ${ }^{2}$
}

${ }^{I}$ Department of Veterinary and A H Extension, College of Veterinary Science and Animal Husbandry, OUAT, Bhubaneswar-751003, Odisha, India

${ }^{2}$ Department of Veterinary and A H Extension Education, College of Veterinary Science and Animal Husbandry, BAU, Ranchi, Jharkhand, India

*Corresponding author

A B S T R A C T

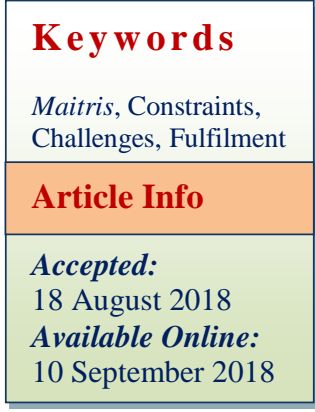

\section{Introduction}

Chhattisgarh farming system is dominated by small and landless farmers who besides agriculture heavily depend on livestock for their livelihood.

The state is bestowed with large number of livestock across the species but their productivity level is very low. In the last two to three decades, it has been observed that the contribution of agriculture sector to gross domestic product (GDP) has been in declining trend whereas the contribution from livestock
The present investigation was carried out in four districts of Chhattisgarh state to assess the challenges and constraints faced by Maitris in delivering the livestock veterinary services in the rural areas. Most of the Maitris stated that people do not pay properly for their services $(74 \%)$, people expect to provide service as like veterinary officers of the department $(91 \%)$, remuneration paid by government for their service is not satisfactory (95\%), and not earning enough from the profession (60\%). Most of the Maitiris $(88 \%)$ also reported that their income is affected as the department officials are providing minor erinary services in their areas. From the study it was found that irregular payment by second most important constraint for Maitris. Irregular and untimely supply of liquid nitrogen and semen was ranked tenth by most of the Maitris. 
continue to earn their livelihood from this occupation. The livestock wealth of Chhattisgarh is impressive in numbers across all species, constituting a natural resource base with immense livelihood implications, even though productivity levels are very low. This sector is a major contributor to rural employment next to agriculture. Provision of adequate livestock service is a prerequisite for increasing the production potentiality of livestock. Outline dispensaries and AI sub centres operated under the Livestock Development Department under Government of Chhattisgarh are the main source of veterinary services to all categories of livestock owners. The above institutions mostly provide curative health services, vaccination, artificial insemination and limited extension services.

In order to supplement the effort of the livestock development department to provide veterinary services to livestock owners of Chhattisgarh, Government of Chhattisgarh has introduced various private partners in the service delivery system. The private players like BAIF and JK Trust have been providing Artificial Insemination (AI) and Veterinary First Aid (VFA) services in the rural areas. Besides, Government of Chhattisgarh through National Project on Cattle and Buffalo Breeding (NPCBB) project has developed private AI workers named as Multipurpose Artificial Insemination Technician in Rural India (MAITRIs) in Chhattisgarh to provide AI services, vaccination, VFA at door step and also motivate farmers for genetic up-gradation of cattle and buffalo.

Since last 11 to 12 years, they have been providing services in the rural areas with active cooperation and guidance of the veterinary department. In spite of the best effort of the Chhattisgarh Government to retain them in service, many of them are not showing much interest to continue in the profession and they are periodically opting out. The present investigation was carried out to know the challenges and constraints faced by the Maitiris in delivering the livestock services in the rural areas.

\section{Materials and Methods}

Four districts viz. Balodabazar, Dhamtari, Gariyaband and Mahasamund of Raipur Division of Chhattisgarh State was selected purposively for the study due to large population of livestock, good track record of A.I done and large number of Maitris working in these districts. From each district, 25 Maitris were selected randomly and in total 100 Maitris were selected as respondents of the study. To measure the challenges faced by Maitiris, 10 statements on different aspects related to challenges in delivering livestock services in the field situations were developed and validated with the help of experts. Responses of the respondents were recorded against each statement with the help of 5-point continuum scale staring from strongly agree to strongly disagree.

Similarly, to rank the constraints, 10 questions related to various aspects of livestock constraints were developed and they were validated by highly experienced experts of the different Departments of Veterinary College and Animal Husbandry Department of Government of Chhattisgarh. The respondents were to rank 10 statements according to the level of their difficulty, constraints faced mostly by them as first and least as tenth rank. After giving rank to each statement calculate percent position with the help of formula. Garret Ranking method was followed to rank the constraints. Statement which had highest average score was ranked as first or constraints faced mostly by Maitris and statement which had low average score was ranked tenth or least constraints faced by them. 


\section{Results and Discussion}

\section{Challenges faced by Maitris}

The findings of challenges faced by Maitris in field situations are summarized and presented in table 1 . Most of the respondents agreed (74\% strongly agreed and 26\% agreed) that people are not paying them properly for their services. On the same way, most of respondents (9\% strongly agreed and 91\% agreed) stated that people are expecting treatment as like provided by A.V.F.O and veterinary officers from them. Most of the respondents (80\%) did not see the V.A.S/AV.F.O as their competitors whereas only $9 \%$ of respondents agreed that they see them as their competitors.

Most of the respondents (95\% strongly agreed and $5 \%$ agreed) that remuneration paid by the Government is not satisfactory. The Maitrais of the study area strongly believed that they are underpaid by both Government as well as farmers, which may be a major hindrance in maintaining their livelihood. Similar types of findings were reported by Swain, D and Das, B C (2017) in their study of Gomitras in Odisha. Most of the respondents believe (94\% strongly agreed and 6\% agreed) that they require more training to handle day to day work which will enhance their capabilities and technical soundness. As they are working in the grass root level, most of the respondents (7\% strongly agreed and $77 \%$ agreed) think that people have more expectation as a clinician than an AI worker. Most of the respondents in selected districts (22\% strongly agreed and $78 \%$ agreed) thought that financial insecurity compels to opt this profession as a secondary source of income which hampers their performance. This shows that respondents are working in the field of AI on part time basis. Again most of the respondents (60\% strongly agreed and 25\%agreed) feel that they are not earning enough from this profession. This may have forced them to indulge in some other activities to earn some money for their livelihood and this may be the reason why they are considering veterinary service as a part time occupation not a fulltime job. However, $85 \%$ of the respondents disagreed that department is involving them in non-remunerative activities. The majority of the respondents $(88 \%$ agree and $12 \%$ strongly agree) stated that as the V.A.S/AV.F.O are providing minor veterinary services in their areas which has contributed to their low earning from this occupation.

\section{Constraints faced by Maitris in delivering Livestock Services}

The analysis of constraints faced by the Maitris in delivering livestock services in the rural areas derived by Garret ranking method is presented in table 2 which reveals that irregular payment by government was ranked first by the respondent followed by lack of refresher training. Unable to do work due to lack of knowledge and skill was ranked third, poor incentives from department ranked fourth and poor quality semen was ranked fifth by the Maitris. Poor cooperation from villagers, low payment to my service by villagers and non-cooperation of V.A.S and A.V.F.O were ranked sixth, seventh and eighth, respectively. Communication problem was ranked ninth and untimely supply of liquid nitrogen and semen ranked tenth. These findings show that the performance of Maitris was affected mostly due to irregular payment by government, lack of refresher training, lack of knowledge and skill low compensation from the farmers and department. Similar types of findings have been reported by various authors in their studies of para-veterinarians providing livestock health services in the rural areas (Ahuja et al., 2003; Rajashree and Subramanina, 2003; Kathiravan et al., 2007; Bardhan, 2010; Swain and Das, 2016). 
Table.1 Challenges faced by Maitris $(\mathrm{n}=100)$

\begin{tabular}{|l|l|c|c|c|c|c|c|}
\hline \multicolumn{1}{|c|}{ Statements } & \multicolumn{4}{|c|}{ Extent of opinion } \\
\hline
\end{tabular}

Table. 2 Constraints faced by Maitris in delivering livestock services

\begin{tabular}{|l|l|l|l|l|}
\hline Order & Statement & Total & A verage score & Rank \\
\hline A & Irregular payment by government & $6425 / 100$ & 64.25 & I \\
\hline B & Poor quality semen & $5404 / 100$ & 54.04 & V \\
\hline C & Untimely supply of Liquid Nitrogen and semen & $2217 / 100$ & 22.17 & X \\
\hline E & $\begin{array}{l}\text { Low payment to my service by the villagers } \\
\text { Communication problem }\end{array}$ & $5272 / 100$ & 52.72 & VII \\
\hline F & $\begin{array}{l}\text { Unable to do the work due to lack of knowledge } \\
\text { and skill }\end{array}$ & $5016 / 100$ & 40.16 & IX \\
\hline G & $\begin{array}{l}\text { Lack of refresher training } \\
\text { P }\end{array}$ & Poor incentives from department & $5780 / 100$ & 57.80 \\
\hline I & Non-cooperation of V.A.S and A.V.F.O & $5437 / 100$ & 54.37 & III \\
\hline J & Poor cooperation from villagers & $4464 / 100$ & 44.64 & IV \\
\hline
\end{tabular}


On the basis of these observations, it can be concluded that to develop a sustainable livestock services delivery network in the rural areas of Chhattisgarh through these Maitiris, their problems and challenges must be addressed by the State Department on priority basis. The Government of Chhattisgarh may adopt suitable strategies in favour of Maitris so that they could have decent earning to stay in profession to serve the rural people.

\section{References}

Ahuja V, McConnel KE, Umali-Deinenger D and DeHaan C. 2003. Is the poor willing to pay for livestock services? Evidence from rural India, Indian Journal of Agricultural Economics, 58 (1): 84-97.

Bardhan D. 2010. Factors influencing farmers willingness to pay for animal health services and preference for private veterinary practitioners, Indian Journal of Animal Sciences, 80(8):790-797.

Husbandry Services in Jagatsinghpur District of Odisha. Unpublished thesis, submitted to Orissa University of agriculture and technology.

Kathiravan G, Thirunavukkarasu M and Michealraj P. 2007. Willingness to pay for animal health care services in small ruminants: The case of South India,
Journal of Applied Sciences, 7 (16): 2361-2365.

Maiti S. 2007. Role Performance and Job Satisfaction among Prani Bandhus of Purba Medinipur district (West Bengal). Thesis submitted to National Dairy Research institute.

Meena MS and Malik BS. 2009. Participatory identification of reproductive problems among dairy animals and constraints faced by farmers in Haryana. Indian Journal of Animal Sciences, 79(11): 1172.

Patil AP. Gawande SH. Nande MP. and Gobade MR. 2009. Constraints faced by the dairy farmers in Nagpur District while Adopting Animal Management Practices, Veterinary world, 2(3):111112.

Rajasree B and Subramanian R. 2003. Willingness of farmers to pay for Animal Husbandry Extension Services, Journal of Extension Education, 14:3543-3549.

Rajendran K. and Mohanty S. 2004. Dairy Co-operatives and Milk Marketing in India: Constraints and Opportunities. Journal of Food Distribution Research, 35:34-41.

Swain DP and Das BC. 2016. Performance of Gomitra in delivering Veterinary and Animal

\section{How to cite this article:}

Chandraker, K., B.C. Das, P. Swain, D.P. Swain, A. Kumar Pandey and Singh, B.K. 2018. Challenges and Constraints Faced by Maitris in Delivering Veterinary Services in Chhattisgarh, India. Int.J.Curr.Microbiol.App.Sci. 7(09): 2722-2726.

doi: https://doi.org/10.20546/ijcmas.2018.709.337 